Lìga Stikāne, Dr. iur. cand.

PhD Candidate, Faculty of Law, University of Latvia, Latvia

\title{
THE RIGHT OF THE SPOUSES TO CHOOSE THE LAW APPLICABLE TO THEIR MATRIMONIAL PROPERTY REGIME IN A MARITAL AGREEMENT
}

\section{LAULĀTO TIESİBAS LAULİBAS LĪGUMĀ IZVĒLĒTIES VIN̦U MANTISKAJĀM ATTIECĪBĀM PIEMĒROJAMO LIKUMU}

\begin{abstract}
Kopsavilkums
Rakstā vispirms ir izpētīta laulības līguma vēsture un noskaidrots laulības līguma tiesiskais regulējums dažādu valstu gimenes tiesỉbās. Pēc tam Latvijas Civillikuma (CL) 13. pants, kas nosaka pārrobežu laulāto mantiskajām attiecībām piemērojamo likumu, ir salīdzināts ar attiecīgajām citu Eiropas valstu kolīziju normām, kā arī ar Laulāto mantisko attiecību regulas un Ziemel̦valstu Laulības konvencijas kolĩziju normām. Tā kā secināms, ka tikai Latvijā pārrobežu laulātajiem nav pieškirtas tiesības izvēelēties viṇu mantiskajām attiecībām piemērojamo likumu, rakstã ierosināts CL 13. pantā nostiprināt pušu autonomiju, l̦aujot pārrobežu laulātajiem izvēlēties viņu mantiskajām attiecībām piemērojamo likumu laulības līgumā. Rakstā ir arī pamatots tas, kādēḷ ši pārrobežu laulāto izvēle būtu jāierobežo.
\end{abstract}

Atslēgvārdi: kolīziju normas, piemērojamais likums, pārrobežu laulība, laulības līgums, pušu autonomija

\section{Summary}

Firstly, this paper explores the history of marital agreements and discovers the present legal framework of marital agreements in the family laws of different countries. Afterwards, Article 13 of the Latvian Civil Law, which stipulates the law applicable to a matrimonial property regime, is compared with the relevant conflict-of-laws rules of other European countries, as well as the conflict-of-laws rules enshrined in the Regulation on Matrimonial Property Regimes and in the Nordic Convention on Marriage. Since only in Latvia cross-border spouses are not allowed to choose the law applicable to their matrimonial property regime, this paper suggests supplementing Article 13 of the Latvian Civil Law with party autonomy, allowing cross-border spouses to choose the law applicable to their matrimonial property regime in a marital agreement. This paper also substantiates why the choice of the cross-border spouses should be limited.

Keywords: conflict-of-laws, applicable law, cross-border marriage, marital agreement, party autonomy 


\section{Introduction}

One of the main legal consequences of marriage at least in the civil law systems ${ }^{1}$ is that it establishes a statutory matrimonial property regime between the spouses. There are different types of statutory matrimonial property regimes in various jurisdictions, but these can be roughly reduced to either a community of property of spouses or a separation of property of spouses. Since the default matrimonial property regime cannot be suited to every marital couple, the possibility and necessity for some couples to devise a matrimonial property regime that better suits their needs was recognised by legislators relatively early on and relevant provisions have been included in various family law codifications. ${ }^{2}$ Thus, spouses are usually allowed to conclude an agreement by which they seek to regulate their property relationship during marriage and in the case of divorce, often by selecting a particular matrimonial property regime. This agreement is called a marital agreement. ${ }^{3}$ Despite party autonomy in concluding a marital agreement, usually there are some specific formal requirements for this agreement. ${ }^{4}$

For centuries the family laws of many countries have recognised party autonomy and have allowed spouses to enter into a marital agreement whereby they choose their matrimonial property regime. It may seem that, if the spouses are allowed to enter into a marital agreement to choose their matrimonial property regime, there is no reason why they should not be allowed to choose the law to govern it. Yet, the right of the spouses in a cross-border marriage to choose the law applicable to their matrimonial property regime in a marital agreement is a very recent occurrence in conflict-of-laws and is not yet accepted even in some EU Member States, for instance, in Latvia. ${ }^{5}$

The aim of this article is, first of all, to discover the history and the main aspects of present legal framework of marital agreements in Europe, the United States of America

Countries, which belong to the legal circle of continental Europe.

2 Scherpe J. M. The Financial Consequences of Divorce in a European Perspective. In: Scherpe J. M. (ed.). European Family Law. Vol. III. Family Law in a European Perspective. Cheltenham: Edward Elgar Publishing, 2016, pp. 197-198.

3 In legal literature, the author has come across various terms in this respect. Usually this agreement is called a marital agreement or a marital property agreement. Sometimes it is called a marriage settlement. Alternatively, depending on when the agreement has been concluded it may be called a prenuptial agreement, an ante-nuptial contract or a postnuptial agreement.

4 One of the most common requirements is that it needs to be contained in a notarial deed. There may be many reasons for entering into a marital agreement, but here are the main three benefits. Firstly, a marital agreement allows each spouse to deal with his or her property without the consent of the other spouse during marriage, secondly, it protects the other spouse from the 'negative effects' of a community of property, namely, from the potential liability for the one spouse's debts and, thirdly, if the spouses decide to divorce, a marital agreement facilitates ending the marriage. As a result of various family law reforms that took place in the 20th century, divorce has now become much more common than ever before, particularly in the European Union (EU), where, according to Eurostat, almost half of the marriages end in divorce. It should be mentioned that according to this data (1960-2016) the highest crude divorce rate among EU Member States is in Latvia and Lithuania. Eurostat. Marriage and Divorce Statistics. Available at: https://ec.europa.eu/eurostat/statistics-explained/index.php/ Marriage_and_divorce_statistics\#Fewer_marriages.2C_more_divorces [last viewed May 10, 2019].

5 This is because party autonomy has only recently established its prominent position in private international law and some countries have not yet amended their national conflict-of-laws rules correspondingly. 
(USA), Latin America (particularly Mexico), Japan and China. Secondly, this paper aims to compare Article 13 of the Latvian Civil Law on the law applicable to matrimonial property regime with the respective conflict-of-laws rules of several other European countries, the rules enshrined in the recently adopted EU Regulation (Council Regulation (EU) 2016/1103 of 24 June 2016 implementing enhanced cooperation in the area of jurisdiction, applicable law and the recognition and enforcement of decisions in matters of matrimonial property regimes) and the provisions of the recently amended 1931 Nordic Convention on Marriage (the Convention of 6 February 1931 between Denmark, Finland, Iceland, Norway and Sweden comprising conflict of laws' provisions on marriage, adoption and guardianship).

The purpose of this comparison is to suggest the best possible amendment to Article 13 of the Latvian Civil Law. This amendment is targeted at modernising Article 13 by supplementing it with the principle of party autonomy, namely, by allowing the cross-border spouses to choose the law applicable to their matrimonial property regime in a marital agreement. It must be emphasized that this paper will argue as to why the choice of the applicable law in this case should only be done in a marital agreement which is contained in a notarial deed and will explain why the choice of the applicable law should be limited.

\section{Historical overview and the present legal framework of marital agreements}

As always, when exploring the history of a legal concept, one should start with taking a look at Roman law on the particular subject. The concept of marital agreement was very well known in Ancient Rome and many rules of Roman law referred to marital agreements between prospective spouses or their families. ${ }^{6}$

The history of present marital agreements began in the $19^{\text {th }}$ century, when the Enlightenment led to the formation of many new national states in Europe. These states adopted their national laws in various sub-branches of law, often in the form of a codification. The most prominent ones were the civil codes, which also contained family law provisions. Of course, these brand new codifications were based on the ideas of Enlightenment. The modern ideas of Enlightenment led to unification and reforms in the family laws of the older countries, too. ${ }^{7}$ In contrast to marriage and divorce law, the law on matrimonial property already in the $19^{\text {th }}$ century usually allowed contractual freedom of the spouses. For instance, under the Austrian Allgemeines Bürgerliches

6 These agreements were called pacta nuptialia or pacta antenuptialia or pacta ante nuptias. One of the most recurring elements of these marital agreements was the right of the spouses to provide for the restitution of the dowry. Oberto G. Prenuptial Agreements in Contemplation of Divorce: European and Italian Perspectives. In: Queirolo I., Heiderhoff B. (eds.). Party Autonomy in European Private (and) International Law. Tome 1. Ariccia (RM): ARACNE, 2015, pp. 222-223.

7 The three most important civil codes adopted at this time were the Prussian Allgemeines Landrecht für die Preussischen Staaten of 1794, the French Code civil of 1804 and the Austrian Allgemeines Bürgerliches Gesetzbuch of 1811. Antokolskaia M. Harmonisation of Family Law in Europe: a Historical Perspective. a Tale of Two Millennia. Antwerpen: Intersentia, 2006, pp. 196, 456. 
Gesetzbuch of 1811 the separation of property was the statutory matrimonial property regime, but spouses had the right to modify this regime by a marital agreement. ${ }^{8}$

As a result of Napoléon Bonaparte's (1769-1821) expansion, the French Code Civil of 1804 was exported to many countries in continental Europe $e^{9}$ and was the main influence on the $19^{\text {th }}$ century civil codes of most countries of continental Europe and Latin America. ${ }^{10}$ Therefore, ever since the beginning of the $19^{\text {th }}$ century spouses in almost all civil law systems have been more or less free to enter into a marital agreement. ${ }^{11}$ Thus, for 200 years in almost all European countries spouses have enjoyed party autonomy to enter into a marital agreement. ${ }^{12}$

In contrast, the common law system has no general notion of statutory matrimonial property regime and marital agreement. ${ }^{13}$ While under common law it is possible though not common to enter into a marital agreement to regulate the property consequences upon and during marriage, ${ }^{14}$ for a long time in common law jurisdictions marital agreements concluded in order to regulate the property consequences upon possible divorce were considered to be contrary to public policy since they undermine the concept of marriage as a life-long union. ${ }^{15}$ Thus, marital agreements were regarded as legally unenforceable and irrelevant to the exercise of the courts

8 Ibid., p. 202. It is important to stress that this was not just a theoretical right. Already in the 19th century spouses were actively using their right to conclude a marital agreement. Marital agreements were particularly popular in France. In 1835 French author Honoré de Balzac (1799-1850) even wrote his novel Le contrat de mariage on this subject, describing the long and intricate negotiations that took place in aristocratic and bourgeois families in France during the drafting process of a marital agreement. H. de Balzac famously wrote that to enter into a marital agreement is the holiest duty of a couple that is about to get married. The exact phrase $\mathrm{H}$. de Balzac used in French was: «Le contrat, mon enfant, est le plus saint des devoirs.» de Balzac H. Le contrat de mariage. Lausanne: Éditions Rencontre, 1968, p. 59.

9 Antokolskaia M., p. 200.

10 The Editors of Encyclopædia Britannica. Napoleonic Code. France [1804]. Available at: https:// www.britannica.com/topic/Napoleonic-Code [last viewed May 7, 2019].

11 Antokolskaia M., p. 455.

12 For instance, in Germany party autonomy began to play a key role in the 19th century, reflecting the thoughts of the greatest German philosophers of the time. For example, the famous German philosopher Georg Wilhelm Friedrich Hegel (1770-1831) once said that marriage contracts (Ehepakten) are intended to regulate relationship between spouses in the case of separation of marriage by natural death, divorce or similar events (gegen den Fall der Trennung der Ehe durch natürlichen Tod, Scheidung u.dergl.). Hegel G. W. F. Grundlinien der Philosophie des Rechts. Leipzig: Felix Meiner Verlag, 1930, p. 147. It should be noted though that family law provisions in socialist legal systems applied a community of property to all spouses without any possibility of deviating from it. See, for instance, Article 25 of the Marriage and Family Code of the Latvian Soviet Socialist Republic. Latvijas Padomju Sociālistiskās Republikas Laulības un gimenes kodekss. Rìga: Liesma, 1977, 16. lpp. As a result, marital agreements in Eastern European countries were introduced or reintroduced only after the fall of the communist regimes. Pintens W. Matrimonial Property Law in Europe. In: Boele-Woelki K., Miles J., Scherpe J. M. (eds.). The Future of Family Property in Europe. Cambridge: Intersentia, 2011, p. 37.

13 Antokolskaia M., p. 455.

14 Pintens W., p. 37.

15 Ibid., p. 40. 
discretionary power to reallocate the property of the spouses. ${ }^{16}$ This is a very significant difference between the civil law countries and common law countries and it is extremely important in the case of a cross-border marriage, since at least in the past a marital agreement which had been concluded abroad might not have been recognised in a common law jurisdiction, for instance, in England and Wales. ${ }^{17}$

Turning now to the legal framework of marital agreements in those countries, where these agreements are permitted, here the main question is how to strike the right balance in protecting a couple's autonomy and protecting them from the consequences that may flow from the exercise of his or her own (or their) autonomy ${ }^{18}$, namely, how to strike a balance between party autonomy of the spouses and the ensuring of fundamental fairness for the economically vulnerable spouse upon divorce. ${ }^{19}$ First of all, almost universally there are formal requirements which have to be met: both parties need to be present at the same time and the marital agreement must be signed by both parties. ${ }^{20}$ Yet, the most common requirement is that the marital agreement needs to be contained in a notarial deed. ${ }^{21}$

16 Antokolskaia M., p. 468. Therefore, to this day England and Wales, Northern Ireland and Ireland do not have a statutory matrimonial property regime and in these jurisdictions the discretion of the court is exercised holistically, by looking at the entirety of the facts and the circumstances of the particular divorce case. Scherpe J. M., p. 165.

17 However, it should be noted that at least in England and Wales the attitude in this respect has begun to change since the historic judgment in Radmacher v. Granatino in 2010. This was a case on a German marital agreement and in its landmark judgment the Supreme Court held, 'The court should give effect to a nuptial agreement that is freely entered into by each party with a full appreciation of its implications unless in the circumstances prevailing it would not be fair to hold the parties to their agreement.' Radmacher (formerly Granatino) (Respondent) v. Granatino (Appellant). [2010] UKSC 42, para. 75. Available at: https://www.supremecourt.uk/cases/docs/uksc-2009-0031-judgment.pdf [last viewed May 9, 2019]. Yet there is still the question, if binding marital agreements were to be introduced in England and Wales, what should be the precondition of their validity and the circumstances in which the court should nevertheless have discretion to set aside the marital agreement. For instance, notaries in this jurisdiction have a specialised role and are not involved in private family law; nor is there a tradition of using one lawyer to legally advise both parties to an agreement. Cooke E. Marital Property Agreements and the Work of the Law Commission for England and Wales. In: Boele-Woelki K., Miles J., Scherpe J. M. (eds.). The Future of Family Property in Europe. Cambridge: Intersentia, 2011, pp. 107-108.

${ }_{18}$ Miles J., Scherpe J. M. The Future of Family Property in Europe. In: Boele-Woelki K., Miles J., Scherpe J. M. (eds.). The Future of Family Property in Europe. Cambridge: Intersentia, 2011, p. 429.

19 Dethloff N. Contracting in Family Law: a European Perspective. In: Boele-Woelki K., Miles J., Scherpe J. M. (eds.). The Future of Family Property in Europe. Cambridge: Intersentia, 2011, p. 68.

20 Ibid., p. 74.

${ }^{21}$ Pintens W. Matrimonial Property Law in Europe. In: Boele-Woelki K., Miles J., Scherpe J. M. (eds.). The Future of Family Property in Europe. Cambridge: Intersentia, 2011, p. 38. This is because when performing a notarisation the notary is obliged to provide independent legal advice to both parties, thus this requirement aims to ensure the protection of the weaker and less informed spouse. Dethloff N., p. 74. Besides, in some jurisdictions there are time requirements in respect of marital agreements. For example, in Catalonia marital agreements which are concluded before marriage (the so-called pre-nuptial agreements) must be entered into at least one month before the wedding. Scherpe J. M., pp. 199-201. Meanwhile in Portugal marital agreements which are concluded after the wedding (the so-called post-nuptial agreements) are impermissible. Pintens W., p. 38. In France since the 19th century according to Article 1397 para. 1 of the Code civil such agreements used to only be allowed after two years of marriage. Code civil. Ancienne version. Available at: https://www.legifrance.gouv.fr/ 
Secondly, there are some substantive requirements for marital agreements. As a starting point, the general rules of contract law apply. Thus, marital agreement may not be the result of a mistake, fraud, threat or coercion and it must not be contrary to morality or public policy. ${ }^{22}$ But that is just the starting point since the family context requires some specific rules in order to protect the actual autonomy of the parties. ${ }^{23}$

The legal framework of marital agreements in the USA, Mexico, Japan and China is similar, but there are, admittedly, some specifics. Although the USA is a common law country, marital agreements there are widely known and practised. ${ }^{24}$ The American Law Institute's Principles of the Law of Family Dissolution require that the marital agreement (a prenuptial agreement or a 'prenup' as it is usually called in the USA) is entered into at least 30 days before the celebration of marriage in order to consult counsel or otherwise consider properly the implications of the marital agreement. ${ }^{25}$

Mexico was the first country in Latin America which already in the $19^{\text {th }}$ century offered couples a formal choice regarding their matrimonial property regime. According to the present Federal Civil Code of 1928, if the couple decides to enter into a marital agreement (capitulaciones matrimoniales) they may choose between a separation of property and a participation in profits (the gananciales regime, termed sociedad conyugal) stipulating, who in the family manages the common property. ${ }^{26}$ The legal

affichCode.do;jsessionid=E733A569D6F9F97797CA8F4A1C1882BF.tplgfr29s_2?idSectionTA=LE GISCTA000006136353\&cidTexte $=$ LEGITEXT000006070721\&dateTexte $=20180509$ [last viewed May 10, 2019]. This provision was amended on 23 March 2019 and now it is not necessary to wait until two years have passed since the establishment of the statutory matrimonial property regime. Loi n ${ }^{\circ} 2019-222$ du 23 mars 2019 de programmation 2018-2022 et de réforme pour la justice (1). Available at: https://www.legifrance.gouv.fr/affichTexteArticle.do;jsessionid=E733A569D6F9F97797CA8F4A1C1882BF.tplgfr29s_2?cidTexte=JORFTEXT000038261631\&idArticle=LEGIARTI $000038262756 \&$ dateTexte $=20190325$ [last viewed May 10, 2019].

22 Dethloff N., pp. 76-77.

23 Scherpe J. M., pp. 198-199. It should be pointed out that when the marital agreement is invoked, the courts in most jurisdictions consider that by concluding a marital agreement it is generally not possible to contract out of providing for the existing needs of the other spouse and compensation (usually known as spousal maintenance). Ibid., p. 204. Therefore it is possible to conclude that in all jurisdictions where marital agreements are allowed their review takes place in two stages: first, certain specific formal and/or procedural requirements need to be met in order for the marital agreement to have any legal relevance (this stage is about procedural fairness); once the marital agreement has satisfied the first stage, the scrutiny moves to the substance of the marital agreement and the court has the right to disregard the marital agreement in certain circumstances (this stage is about substantive fairness). Ibid., pp. 205-206.

24 Oberto G., p. 225.

25 The American Law Institute. Principles of the Law of Family Dissolution: Analysis and Recommendations. St. Paul (Minnesota): American Law Institute Publishers, 2002, p. 960. In the USA a marital agreement can determine not only what happens if the spouses divorce, but also what happens when they die. Furthermore, a so-called sunset provision may be inserted into a marital agreement, specifying that after a certain period of time the agreement will expire. Interestingly, in a couple of states, for example, Maine, the marital agreement automatically lapses after the birth of a child, unless the spouses renew their agreement. Oberto G., pp. 226-227.

26 The participation in profits, which is a type of a community of property, is the default regime. Yet only future studies of Mexican divorce proceedings could shed light on how often spouses do enter into a marital agreement and what kind of arrangements are most common. At present this information is unavailable. Deere C. D. Married Women's Property Rights in Mexico. a Comparative Latin American Perspective and Research Agenda. In: Baitenmann H., Chenaut V., Varley A. (eds.). 
situation of women in other Latin American countries is not so good. Argentina, Chile and Nicaragua have not even yet granted husbands and wives equal rights in marriage. Most women in Latin America are unaware that they have a choice of a matrimonial property regime. ${ }^{27}$

Pursuant to Article 755 of the Japanese Civil Code (Minpô), which was also adopted in the $19^{\text {th }}$ century, if, prior to giving notification of the marriage, the spouses have not entered into a marital agreement which provides otherwise regarding their property, the property relations of husband and wife are prescribed by the provisions of Minpô. ${ }^{28}$ Notably, the spouses may choose to enter into a marital agreement without any restrictions since there are no requirements regarding the form and substance of the marital agreement. ${ }^{29}$ The only rule is that it has to be registered prior to the notification of the marriage (Article 756, Minpô) ${ }^{30}$ It should be noted that in practice marital agreements in Japan are concluded extremely rare and there are no Japanese judgments available regarding marital agreements. ${ }^{31}$

The current Marriage Law of the People's Republic of China (China) of 2001 is based on its Marriage Law of 1980. Article 13 of the Marriage Law of 1980 determined that all the property acquired by husband and wife during marriage would be considered joint marital property unless the spouses had agreed otherwise. ${ }^{32}$ Article 19 para. 1 of the Marriage Law of 2001 stipulates that the spouses may enter into a marital agreement and that the marital agreement shall be in written form. ${ }^{33}$ Thus,

Decoding Gender: Law and Practice in Contemporary Mexico. New Brunswick (New Jersey): Rutgers University Press, 2007, pp. 213, 215, 217, 226.

27 Moreover, civil functionaries and judges rarely inquire as to a couple's preference regarding their matrimonial property regime or ask if they would like to enter into a marital agreement. Thus, this option is only available to educated people who are familiar with their country's civil code. Deere C. D., 225-226.

28 Japanese Civil Code (Minpô). Act No. 89 of 27 April 1896. Available at: http://www.japaneselawtranslation.go.jp $/$ law $/$ detail $/ ? \mathrm{ft}=2 \& \mathrm{re}=2 \& \mathrm{dn}=1 \& \mathrm{yo}=$ Civil + Code $\& \mathrm{x}=47 \& \mathrm{y}=8 \& \mathrm{ia}=03 \& \mathrm{ph}=$ $\& \mathrm{ky}=$ \&page $=5$ [last viewed May 10, 2019].

29 Hotz S. Understanding Legal Culture through the Intersection of Law, Culture and Gender - an Example from Japanese Family Law. Journal of Comparative Law. Butler W. E., Palmer M. (eds.). Vol. V, Issue 2, 2010, p. 201.

30 Japanese Civil Code (Minpô). Act No. 89 of 27 April 1896. Available at: http://www.japaneselawtranslation.go.jp $/$ law $/$ detail $/ ? \mathrm{ft}=2 \& \mathrm{re}=2 \& \mathrm{dn}=1 \& \mathrm{yo}=\mathrm{Civil}+\mathrm{Code} \& \mathrm{x}=47 \& \mathrm{y}=8 \& \mathrm{ia}=03 \& \mathrm{ph}=$ $\& \mathrm{ky}=\&$ page $=5$ [last viewed May 10, 2019]. It is very interesting to note that while in Japan the statutory matrimonial property regime is the separation of property (Article 762 para. 1, Minpô) and although $90 \%$ of the main family breadwinners are men, family finances are handled only by women and it is the wife who decides on her husband's 'pocket money', Hotz S., p. 208.

31 Hotz S., p. 202.

32 Marriage Law of the People's Republic of China (adopted at the Third Session of the Fifth National People's Congress and promulgated by Order No. 9 of the Chairman of the Standing Committee of the National People's Congress on 10 September 1980, and effective as of 1 January 1981). Available at: http://www.asianlii.org/cn/legis/cen/laws/mlotproc354/ [last viewed May 11, 2019].

33 Marriage Law of the People's Republic of China (adopted at the Third Session of the Fifth National People's Congress on 10 September 1980 and promulgated by Order No. 9 of the Chairman of the Standing Committee of the National People's Congress on 10 September 1980; and amended in accordance with the Decision on Amending the Marriage Law of the People's Republic of China, adopted at the $21^{\text {st }}$ Meeting of the Standing Committee of the Ninth National People's Congress on 28 April 
the spouses are allowed to conclude a written marital agreement and alter the default regime. In 2001, China's Supreme People's Court issued a legally binding judicial interpretation (as is custom in China) of this provision specifically clarifying that the property designated as separate by both spouses in a prior written agreement shall not become joint property, regardless of the length of the marriage. ${ }^{34}$ From this statement one can conclude that a prior written marital agreement is given a lot of weight by courts during the divorce proceedings. ${ }^{35}$

\section{Comparison of Article 13 of the Latvian Civil Law with the relevant conflict-of-laws provisions of foreign legal acts}

Moving now from family law to private international law, it is necessary to, first, learn the content of the Latvian national conflict-of-laws provision on the law applicable to a matrimonial property regime in a cross-border marriage, namely, Article 13 of the Latvian Civil Law and, secondly, to compare this provision with the conflict-of-laws rules of several other European countries and those enshrined in the recently adopted EU Regulation and the provisions of the recently amended 1931 Nordic Convention on Marriage as regards the right of the cross-border spouses to choose the applicable law.

Article 13 of the Latvian Civil Law (Civillikums) stipulates that if the domicile of the cross-border spouses is in Latvia, their property relationship is regulated by Latvian law. Besides, if the property of the cross-border spouses is located in Latvia, Latvian law applies to this property, even if the cross-border spouses do not have their domicile in Latvia. ${ }^{36}$ Thus, this provision does not contain party autonomy and cross-border spouses are not given a right to choose the law applicable to their property relationship in a marital agreement.

Meanwhile Article 1.28, para. 2 of the Lithuanian Civil Code establishes that, if the cross-border spouses have entered into a marital agreement and chosen their matrimonial property regime, the law applicable to this contractual matrimonial property regime is determined by the law of the country which the cross-border spouses have chosen in their marital agreement. However, the choice of the cross-border spouses is limited - they may choose either the law of the country of their common domicile or the law of the country of their future common domicile, or the law of the country

2001). Available at: http://www.npc.gov.cn/englishnpc/Law/2007-12/13/content_1384064.htm [last viewed May 11, 2019].

34 Chang V. L. No Gold Diggers: China's Protection of Individual Property Rights in the New Marital Property Regime. The George Washington International Law Review. Vol. 45. No. 1, 2013, pp. 151, 161-162.

35 Furthermore, there is a strong preference in China's Marriage Law for spouses to enter into a marital agreement, although traditionally the Chinese are reluctant to use marital agreements to protect their assets because it indicates a 'lack of faith in the relationship and could result in hurt feelings'. However, marital agreements are gaining popularity among younger generations. Ibid., p. 167. Hopefully, in the near future the negative attitude towards marital agreements not only in China but all over the world will end and couples worldwide will be eager to enter into a marital agreement, acknowledging the benefits of such an agreement from a rational point of view.

36 Civillikums: LV Likums. Valdības Vēstnesis, 1937. 20. februāris, Nr. 41. 
in which the cross-border marriage was celebrated, or the law of the country whose national is at least one of the spouses. Besides, this agreement between the crossborder spouses on the applicable law is valid only if it is concluded in compliance with the requirements of the law of the chosen country or with the requirements of the law of the country in which the agreement was made. ${ }^{37}$ Thus, in contrast to the conflict-of-laws rule of the Latvian Civil Law, the relevant Lithuanian Civil Code provision provides for party autonomy by allowing cross-border spouses to choose the country whose law determines the law applicable to their matrimonial property regime in a marital agreement. It is important to stress though that the spousal choice of the applicable law is limited.

According to Article 58, para. 1 of the Estonian Private International Law Act, the law applicable to the property relationship between cross-border spouses is the law the cross-border spouses have chosen. Yet again the choice of the cross-border spouses is restricted - they may choose either the law of the country of residence or the law of the country of nationality of one of the spouses. Furthermore, Article 58, para. 2 specifies that the choice of the applicable law must be notarised. But, if the applicable law is not chosen in Estonia, the choice of law is formally valid if the formal requirements prescribed for marital agreements by the chosen law are complied with. ${ }^{38}$ It is possible to conclude that in Estonian conflict-of-laws the emphasis is put on party autonomy, namely, the right of the cross-border spouses to choose the law applicable to their matrimonial property regime. However, the spousal choice of the applicable law is again limited.

As for the Russian Семейный кодекс, its Article 161, para. 2 establishes that cross-border spouses who enter into a marital agreement and do not have a common nationality or a common residence may choose the law applicable to their property relationship. ${ }^{39}$ Thus, the Russian conflict-of-laws rules also allow cross-border spouses to choose the law applicable to their matrimonial property regime. Notably, the spousal choice of the applicable law is not limited there, yet the right to choose the applicable law is restricted to those cross-border spouses who do not have a common nationality or a common residence.

Pursuant to Article 22, para. 1 of the Council Regulation (EU) 2016/1103 of 24 June 2016 implementing enhanced cooperation in the area of jurisdiction, applicable law and the recognition and enforcement of decisions in matters of matrimonial property regimes (hereinafter - Regulation on Matrimonial Property Regimes) cross-border spouses and future spouses do have a right to enter into an agreement in order to designate the law applicable to their matrimonial property regime. However, their choice of the applicable law is limited - spouses may choose either the law of the country where both of them, or at least one them, is habitually

37 Civil Code of the Republic of Lithuania. Available at: https://e-seimas.lrs.lt/portal/legalAct/lt/ TAD/TAIS.245495 [last viewed May 10, 2019].

38 Private International Law Act of Estonia. Available at: https://www.riigiteataja.ee/en/eli/ee/ 513112013009/consolide/current [last viewed May 11, 2019].

39 Семейный кодекс Российской Федерации. Available at: http://www.semkod.ru/ [last viewed May 11, 2019]. 
resident at the time the agreement is concluded or the law of the country of nationality of either spouse or potential spouse at the time the agreement is concluded. ${ }^{40}$

On 26 January 2006, an agreement was reached to amend the Convention of 6 February 1931 between Denmark, Finland, Iceland, Norway and Sweden comprising conflict of laws' provisions on marriage, adoption and guardianship (hereinafter - the Nordic Convention on Marriage). According to Article 3 (a) of the Nordic Convention on Marriage, spouses who have their domicile in a Nordic state may designate the law applicable to their matrimonial property regime. It is important to note that, if the spouses change their domicile, the chosen law continues to apply only if the spouses settle in another Nordic state. ${ }^{41}$ The choice of the applicable law is limited - spouses may only choose either the law of a Nordic state with which at least one of the spouses has a connection through domicile (lex domicilii) or nationality (lex nationalis) or the law of another Nordic state, in which the spouses had their last common domicile during marriage. ${ }^{42}$

\section{Suggested amendment to Article 13 of the Latvian Civil Law and its substantiation}

Consequently, Latvia is one of the very few exceptions in the EU where crossborder spouses are still not allowed to choose the law applicable to their matrimonial property regime. This can easily be explained by the fact that Article 13 of the Latvian Civil Law was adopted in $1937^{43}$, when the doctrine of private international

40 Council Regulation (EU) 2016/1103 of 24 June 2016 implementing enhanced cooperation in the area of jurisdiction, applicable law and the recognition and enforcement of decisions in matters of matrimonial property regimes. Official Journal of the European Union. 8 July 2016, No. L 183/1. It should be noted that according to recital 11 of the preamble of the Regulation on Matrimonial Property Regimes from 29 January 2019 this legal act has replaced the relevant national conflictof-laws rules of $18 \mathrm{EU}$ Member States - Austria, Belgium, Bulgaria, Croatia, Cyprus, the Czech Republic, Finland, France, Germany, Greece, Italy, Luxembourg, Malta, the Netherlands, Portugal, Slovenia, Spain and Sweden. It should be added that Article 23 para. 1 specifies that this agreement must be expressed in writing, dated and signed by both spouses. This means that just like in the other legal acts already discussed in this paper the emphasis in the Regulation on Matrimonial Property Regimes is put on the right of the cross-border spouses to choose the law applicable to their matrimonial property regime, which is not a surprise since the vast majority of the national conflict-of-laws rules of the Member States have long provided for party autonomy in this respect. Kroll K. Unification of Conflict of Laws in Europe. - Matrimonial Property Regimes - In: BoeleWoelki K., Sverdrup T. (eds.). European Challenges in Contemporary Family Law. Antwerp: Intersentia, 2008, p. 383.

${ }^{41}$ Meurling E. Less Surprise for Spouses Moving within the Nordic Countries? Amendments to the 1931 Nordic Convention on Marriage. In: Šarčević P. (founding ed.), Bonomi A., Volken P. (eds.). Yearbook of Private International Law. Vol. XI, 2009. Published in Association with Swiss Institute of Comparative Law. Lausanne: Sellier European Law Publishers in association with Swiss Institute of Comparative Law, 2010, pp. 385, 386, 387-389. Regarding the form of such an agreement it should be noted that the designation of the applicable law may be included in the marital agreement or be concluded separately or even independently of the existence of a marital agreement. Ibid., p. 389.

42 Ibid., p. 390. On a final note, Article 3 (b) stipulates that the spouses may not choose the law applicable to immovable property. Ibid., p. 391.

43 Civillikums: LV Likums. Valdības Vēstnesis, 1937. 20. februāris, Nr. 41. 
law did not yet recognise party autonomy in the determination of the applicable law. Nowadays, the use of party autonomy as a connecting factor is one of the basic principles of private international law since, for example, it allows cross-border spouses to choose a legally certain, predictable and permanent legal regulation of their matrimonial property regime. Party autonomy also enables to take into account the interests of both cross-border spouses. Besides, it gives the opportunity to avoid the application of the law with which the spouses no longer have a connection and instead allows the spouses to choose the law of the country, with which they have a closer connection. ${ }^{44}$ Party autonomy has even been described as a universal panacea in conflict-of-laws because it triggers the assumption that the law freely chosen by the parties is the proper law, which has the closest connection to the matter. ${ }^{45}$

Conflict-of-laws (and private international law altogether) is not an island isolated from substantial law, but, rather on the contrary, is an important part of private law. ${ }^{46}$ Thus, the conflict-of-laws rules on the law applicable to a matrimonial property regime have a very close connection to the family law provisions on matrimonial property. As has already been discussed in this paper, the family law provisions of most countries allow spouses to enter into a marital agreement. But, if the spouses are not allowed to choose the law applicable to their marital agreement, there is the risk that the marital agreement could be declared void or unenforceable under the law that may turn out to be applicable according to the conflict-of-laws rules. Therefore, party autonomy is crucial to marital agreements. ${ }^{47}$ The freedom of parties to an international agreement to choose the applicable law is almost universally acknowledged. ${ }^{48}$ This should definitely include cross-border spouses who have entered into a marital agreement.

It is because of these reasons that the author suggests an amendment to Article 13 of the Latvian Civil Law in order to supplement it with party autonomy, namely, the author proposes adding a second part to Article 13 in the following wording:

Spouses have the right to choose the law applicable to their matrimonial property relationship, but only if it is the law of the common domicile of the spouses or the last common domicile of the spouses, or the law of the country with which the spouses are otherwise most closely connected, but in respect of immovable property - the law of the

44 Viarengo I. The EU Proposal on Matrimonial Property Regimes. Some General Remarks. In: Šarčević P., Volken P. (founding eds.), Bonomi A., Romano G. P. (eds.). Yearbook of Private International Law. Vol. XIII, 2011. Published in Association with Swiss Institute of Comparative Law. Munich: Sellier European Law Publishers, 2012, p. 210.

45 Nagy C. I. Love and Money: Problems of Characterisation in Matrimonial Property and Maintenance Matters in the European Union. In: Beaumont P., Hess B., Walker L., Spancken S. (eds.). The Recovery of Maintenance in the EU and Worldwide. Oxford: Hart Publishing, 2014, p. 419.

46 González Beilfuss C. The Proposals on Council Regulations in Matters of Matrimonial Property Regimes and on the Property Consequences of Registered Partnerships: Interactions between Private International Law and Substantive Law. In: Lauroba Lacasa E., Ginebra Molins M. E. (eds.). Régimes matrimoniaux de participation aux acquêts et autres mécanismes participatifs entre époux en Europe. Coordonnateur: Jaume Tarabal Bosch. Droit comparé et européen. Volume 23. Paris: Société de législation comparée, 2016, p. 186.

47 Nagy C. I., p. 419.

48 Roodt Ch. Conflict of Law(s) and Autonomy in Antenuptial Agreements. Tydskrif Vir Hedendaagse Romeins-Hollandse Reg. In: Journal of Contemporary Roman-Dutch Law, 2006, p. 367. 
country in which this immovable property is located. In Latvia spouses may make this choice only in a marital agreement. If the choice on the applicable law has been made abroad, it is recognised in Latvia, if it complies with the requirements regarding the form of a marital agreement of the law of the country whose law the spouses have chosen to apply to their matrimonial property relationship or with the requirements regarding the form of a marital agreement of the law of the country where the choice is made.

The author also proposes adding a third part to Article 13 in this wording:

If the spouses have not made an agreement on the law applicable to their property relationship, the law which, according to paragraph one of this Article, would be applicable to the personal relationship between spouses applies, but as regards the immovable property - the law of the country in which this immovable property is located applies. ${ }^{49}$

Having examined the conflict-of-laws rules of other legal acts, the author is of the opinion that the right of cross-border spouses to choose the law applicable to their property relationship should be limited, because it is very important that the applicable law has a close connection to the spouses. ${ }^{50}$ As regards the immovable property, one of the most deep-rooted principles of conflict-of-laws dictates that the law applicable to immovable property is the law of the country in which this property is located (lex situs). ${ }^{51}$ Finally, considering the importance of the legal consequences of the choice of the law applicable to matrimonial property regime, the author believes that, if the choice is made in Latvia, the spouses should only be allowed to make the choice of the applicable law in a marital agreement since in Latvia it is contained in a notarial deed (Article 115, para. 1 of the Latvian Civil Law) ${ }^{52}$, thus ensuring that both spouses realize the legal consequences of their choice.

\section{Conclusions}

1. Although the history of marital agreements already began in Ancient Rome, the history of present marital agreements began in the $19^{\text {th }}$ century as a result of the Enlightenment. The present legal framework of marital agreements as regards both the formal requirements and the substance of such agreements is similar

49 The author has already briefly suggested this amendment of Article 13 of the Latvian Civil Law in one of her papers in Latvian: Stikāne L. Laulāto mantiskajām attiecībām piemērojamā likuma noteikšana Latvijas un citu Eiropas valstu nacionālajās un Eiropas Savienības starptautiskajās privāttiesībās: salīdzinājums. In: Centrālās un Austrumeiropas juridiskās tradīcijas un juridiskās identitātes jautājumi. Latvijas Universitātes 76. starptautiskās zinātniskās konferences rakstu krājums. Rīga: LU Akadēmiskais apgāds, 2018, 194. lpp.

50 Since cross-border spouses usually do not have a common nationality and their property relationship usually is more closely connected to the country in which they have or have had their common domicile, the spouses should be given the right to choose either the law of the country in which they have or have had their last common domicile or the law of the country to which the couple is otherwise most closely connected.

51 McClean D., Ruiz Abou-Nigm V. Morris: The Conflict of Laws. $8^{\text {th }}$ edition of the series. London: Sweet \& Maxwell, 2012, pp. 420, 448.

52 Civillikums: LV Likums. Valdības Vēstnesis, 1937. 20. februāris, Nr. 41. 
in most European countries, the USA, Mexico, Japan and China. In contrast, several common law systems, including England and Wales, do not have general notion of marital agreement.

2. Having compared Article 13 of the Latvian Civil Law with the relevant conflictof-laws rules of Lithuania, Estonia and Russia, as well as those enshrined in the Regulation on Matrimonial Property Regimes and in the Nordic Convention on Marriage, the author concludes that only in Latvia cross-border spouses are still not allowed to choose the law applicable to their matrimonial property regime.

3. Nowadays, the use of party autonomy as a connecting factor is one of the basic principles of private international law since it provides for legal certainty and predictability. For various reasons, party autonomy is particularly crucial to marital agreements. It is because of the various benefits of party autonomy that the author suggests an amendment to Article 13 of the Latvian Civil Law in order to supplement it with party autonomy.

4. Having examined the conflict-of-laws rules of other legal acts, the author is of the opinion that the right of the cross-border spouses to choose the law applicable to their property relationship should be limited.

5. Finally, considering the importance of the legal consequences of the choice of the law applicable to matrimonial property regime, the author believes that, if the choice is made in Latvia, the spouses should only be allowed to make the choice of the applicable law in a marital agreement since in Latvia it is contained in a notarial deed.

\section{BIBLIOGRAPHY}

\section{Literature}

1. Antokolskaia M. Harmonisation of Family Law in Europe: A Historical Perspective. A Tale of Two Millennia. Antwerpen: Intersentia, 2006.

2. Balzac H., de. Le contrat de mariage. Lausanne: Éditions Rencontre, 1968.

3. Chang V. L. No Gold Diggers: China's Protection of Individual Property Rights in the New Marital Property Regime. In: The George Washington International Law Review, Vol. 45. No. 1, 2013, pp. 149-181.

4. Cooke E. Marital Property Agreements and the Work of the Law Commission for England and Wales. In: Boele-Woelki K., Miles J., Scherpe J. M. (eds.). The Future of Family Property in Europe. Cambridge: Intersentia, 2011, pp. 95-113.

5. Deere C. D. Married Women's Property Rights in Mexico. a Comparative Latin American Perspective and Research Agenda. In: Baitenmann H., Chenaut V., Varley A. (eds.). Decoding Gender: Law and Practice in Contemporary Mexico. New Brunswick (New Jersey): Rutgers University Press, 2007, pp. 213-230.

6. Dethloff N. Contracting in Family Law: a European Perspective. In: Boele-Woelki K., Miles J., Scherpe J. M. (eds.). The Future of Family Property in Europe. Cambridge: Intersentia, 2011, pp. 65-94.

7. Eurostat. Marriage and Divorce Statistics. Available at: https://ec.europa.eu/eurostat/statistics-explained/index.php/Marriage_and_divorce_statistics\#Fewer_marriages.2C_more_divorces [last viewed May 10, 2019]. 
8. González Beilfuss C. The Proposals on Council Regulations in Matters of Matrimonial Property Regimes and on the Property Consequences of Registered Partnerships: Interactions between Private International Law and Substantive Law. In: Lauroba Lacasa E., Ginebra Molins M. E. (eds.). Régimes matrimoniaux de participation aux acquêts et autres mécanismes participatifs entre époux en Europe. Coordonnateur: Jaume Tarabal Bosch. Droit comparé et européen. Volume 23. Paris: Société de législation comparée, 2016, pp. 171-187.

9. Hegel G. W. F. Grundlinien der Philosophie des Rechts. Leipzig: Felix Meiner Verlag, 1930.

10. Hotz S. Understanding Legal Culture through the Intersection of Law, Culture and Gender an Example from Japanese Family Law. Journal of Comparative Law. Butler W. E., Palmer M. (eds.). Vol. V, Issue 2, 2010, pp. 194-215.

11. Kroll K. Unification of Conflict of Laws in Europe. - Matrimonial Property Regimes - In: Boele-Woelki K., Sverdrup T. (eds.). European Challenges in Contemporary Family Law. Antwerp: Intersentia, 2008, pp. 379-393.

12. McClean D., Ruiz Abou-Nigm V. Morris: The Conflict of Laws. $8^{\text {th }}$ edition of the series. London: Sweet \& Maxwell, 2012.

13. Meurling E. Less Surprise for Spouses Moving within the Nordic Countries? Amendments to the 1931 Nordic Convention on Marriage. In: Šarčević P. (founding ed.), Bonomi A., Volken P. (eds.). Yearbook of Private International Law. Vol. XI, 2009. Published in Association with Swiss Institute of Comparative Law. Lausanne: sellier european law publishers in association with Swiss Institute of Comparative Law, 2010, pp. 385-394.

14. Miles J., Scherpe J. M. The Future of Family Property in Europe. In: Boele-Woelki K., Miles J., Scherpe J. M. (eds.). The Future of Family Property in Europe. Cambridge: Intersentia, 2011, pp. 432-432.

15. Nagy C. I. Love and Money: Problems of Characterisation in Matrimonial Property and Maintenance Matters in the European Union. In: Beaumont P., Hess B., Walker L., Spancken S. (eds.). The Recovery of Maintenance in the EU and Worldwide. Oxford: Hart Publishing, 2014, pp. 411-423.

16. Oberto G. Prenuptial Agreements in Contemplation of Divorce: European and Italian Perspectives. In: Queirolo I., Heiderhoff B. (eds.). Party Autonomy in European Private (and) International Law. Tome 1. Ariccia (RM): ARACNE, 2015, pp. 221-245.

17. Pintens W. Matrimonial Property Law in Europe. In: Boele-Woelki K., Miles J., Scherpe J. M. (eds.). The Future of Family Property in Europe. Cambridge: Intersentia, 2011, pp. 19-46.

18. Roodt Ch. Conflict of Law(s) and Autonomy in Antenuptial Agreements. Tydskrif Vir Hedendaagse Romeins-Hollandse Reg. Journal of Contemporary Roman-Dutch Law. 2006, pp. 215-226, 367-380, 546-560.

19. Scherpe J. M. The Financial Consequences of Divorce in a European Perspective. In: Scherpe J. M. (ed.). European Family Law. Vol. III. Family Law in a European Perspective. Cheltenham: Edward Elgar Publishing, 2016, pp. 146-208.

20. Stikāne L. Laulāto mantiskajām attiecībām piemērojamā likuma noteikšana Latvijas un citu Eiropas valstu nacionālajās un Eiropas Savienības starptautiskajās privāttiesībās: salīdzinājums. No: Centrālās un Austrumeiropas juridiskās tradīcijas un juridiskās identitātes jautājumi. Latvijas Universitātes 76. starptautiskās zinātniskās konferences rakstu krājums. Rìga: LU Akadēmiskais apgāds, 2018, 189.-194. lpp.

21. The American Law Institute. Principles of the Law of Family Dissolution: Analysis and Recommendations. St. Paul (Minnesota): American Law Institute Publishers, 2002.

22. The Editors of Encyclopædia Britannica. Napoleonic Code. France [1804]. Available at: https://www.britannica.com/topic/Napoleonic-Code [last viewed May 7, 2019]. 
23. Viarengo I. The EU Proposal on Matrimonial Property Regimes. Some General Remarks. In: Šarčević P., Volken P. (founding eds.), Bonomi A., Romano G. P. (eds.). Yearbook of Private International Law. Vol. XIII, 2011. Published in Association with Swiss Institute of Comparative Law. Munich: Sellier European Law Publishers, 2012, pp. 199-215.

\section{Normative acts}

24. Civil Code of the Republic of Lithuania. Available at: https://e-seimas.lrs.lt/portal/legalAct/ lt/TAD/TAIS.245495 [last viewed May 11, 2019].

25. Civillikums: LV Likums. Valdības Vēstnesis, 1937. 20. februāris, Nr. 41.

26. Code civil. Ancienne version. Available at: https://www.legifrance.gouv.fr/affichCode.do;jse ssionid=E733A569D6F9F97797CA8F4A1C1882BF.tplgfr29s_2?idSectionTA=LEGISCTA $000006136353 \&$ cidTexte $=$ LEGITEXT000006070721\&dateTexte $=20180509$ [last viewed May 10, 2019].

27. Council Regulation (EU) 2016/1103 of 24 June 2016 implementing enhanced cooperation in the area of jurisdiction, applicable law and the recognition and enforcement of decisions in matters of matrimonial property regimes. Official Journal of the European Union. 8 July 2016, No. L 183/1.

28. Japanese Civil Code (Minpô). Act No. 89 of 27 April 1896. Available at: http://www.japaneselawtranslation.go.jp/law/detail $/ \mathrm{ft}=2 \& \mathrm{re}=2 \& \mathrm{dn}=1 \& y o=$ Civil + Code $\& \mathrm{x}=47 \& \mathrm{y}=8 \& \mathrm{ia}=03 \&$ $\mathrm{ph}=\& \mathrm{ky}=\&$ page $=5$ [last viewed May 10, 2019].

29. Latvijas Padomju Sociālistiskās Republikas Laulïbas un ǵimenes kodekss. Rìga: Liesma, 1977.

30. Loi n 2019-222 du 23 mars 2019 de programmation 2018-2022 et de réforme pour la justice (1). Available at: https://www.legifrance.gouv.fr/affichTexteArticle.do;jsessionid=E733A5 69D6F9F97797CA8F4A1C1882BF.tplgfr29s_2?cidTexte=JORFTEXT000038261631\&idArticle $=$ LEGIARTI000038262756\&dateTexte $=20190325$ [last viewed May 10, 2019].

31. Marriage Law of the People's Republic of China (adopted at the Third Session of the Fifth National People's Congress and promulgated by Order No.9 of the Chairman of the Standing Committee of the National People's Congress on 10 September 1980, and effective as of 1 January 1981). Available at: http://www.asianlii.org/cn/legis/cen/laws/mlotproc354/ [last viewed May 11, 2019].

32. Marriage Law of the People's Republic of China (adopted at the Third Session of the Fifth National People's Congress on 10 September 1980 and promulgated by Order No.9 of the Chairman of the Standing Committee of the National People's Congress on 10 September 1980; and amended in accordance with the Decision on Amending the Marriage Law of the People's Republic of China, adopted at the $21^{\text {st }}$ Meeting of the Standing Committee of the Ninth National People's Congress on 28 April 2001). Available at: http://www.npc.gov.cn/ englishnpc/Law/2007-12/13/content_1384064.htm [last viewed May 11, 2019].

33. Private International Law Act of Estonia. Available at: https://www.riigiteataja.ee/en/eli/ ee/513112013009/consolide/current [last viewed May 11, 2019].

34. Семейный кодекс Российской Федерации. Available at: http://www.semkod.ru/ [last viewed May 11, 2019].

\section{Court practice}

35. Radmacher (formerly Granatino) (Respondent) v. Granatino (Appellant). [2010] UKSC 42. Available at: https://www.supremecourt.uk/cases/docs/uksc-2009-0031-judgment.pdf [last viewed May 9, 2019]. 